\title{
Effect of prepartal and postpartal dietary fat level on performance and plasma concentration of metabolites in transition dairy cows
}

\author{
M. Karimian, ${ }^{*}$ M. Khorvash, ${ }^{*}$ M. A. Forouzmand,† M. Alikhani, ${ }^{*}$ H. R. Rahmani, ${ }^{*}$ M. H. Ghaffari, ${ }^{*}$ \\ and H. V. Petit $\ddagger^{1}$ \\ *Department of Animal Sciences, College of Agriculture, Isfahan University of Technology, Isfahan 84156 - 83111, Iran \\ †Department of Animal Sciences, College of Agriculture, Yasouj University, Yasouj 75918-74831, Iran \\ ‡Dairy and Swine Research and Development Centre, Agriculture and Agri-Food Canada, 2000 College St., Sherbrooke, QC J1M 0C8, Canada
}

\section{ABSTRACT}

The objective of this study was to determine the effects of 2 levels of dietary fat (low and high) offered during the prepartal and postpartal periods on dry matter intake (DMI), plasma concentration of metabolites, and milk yield and composition. Twenty-four Holstein dry cows were assigned on d 21 relative to expected parturition date to 1 of 4 treatments in a 2 $\times 2$ factorial arrangement of 2 levels of fat fed during the prepartal period and 2 levels of fat fed during the postpartal period: prepartal low fat and postpartal low fat (LF-LF), prepartal low fat and postpartal high fat (LF-HF), prepartal high fat and postpartal low fat (HF-LF), or prepartal high fat and postpartal high fat (HF-HF). Prepartal and postpartal LF diets contained no fat supplement. Prepartal HF diets contained 1.60\% calcium salts of soybean oil. The proportion of calcium salts of soybean oil was increased to $1.70 \%$ of DM for the first $21 \mathrm{~d}$ of lactation and to $2.27 \%$ of $\mathrm{DM}$ from $\mathrm{d}$ 21 to 56 of lactation in the HF diet. Diets were fed for ad libitum intake from d 21 before calving until d 56 of gestation. Prepartal DMI was lower for cows fed the HF diet compared with those fed the LF diet (12.6 vs. 16.2 $\mathrm{kg} / \mathrm{d}$ ). Postpartum, cows fed the HF-HF and HF-LF diets had, respectively, the lowest and highest DMI, although no significant differences existed between HFLF and LF-LF. Net energy intake was higher for cows fed the postpartal HF diets compared with those fed the LF diets. Prepartal fat level had no effect on net energy intake. Cows offered the prepartal HF diet had higher milk yield when offered the postpartal LF diet compared with those offered the postpartal HF diet and no effect of the postpartal fat level was detected when cows were fed the prepartal LF diet. Milk composition was similar among treatments. Plasma cholesterol concentration postpartum was higher for cows fed the prepartal LF diet than for those fed the prepartal

Received October 8, 2013.

Accepted June 22, 2014.

${ }^{1}$ Corresponding author: Helene.Petit@agr.gc.ca
HF diet (5.16 vs. $3.74 \mathrm{mmol} / \mathrm{L})$ and postpartal fat level had no effect. Prepartal diet had no significant effect on postpartal plasma triglyceride concentration but the postpartal HF diet increased triglyceride and low-density lipoprotein concentrations compared with the postpartal LF diet. In conclusion, switching from a high to a low fat proportion in the postpartal diet may alleviate the negative effects of a high proportion of fat in the prepartal diet as shown by increased feed intake and milk production during the first $56 \mathrm{~d}$ of lactation. Key words: dairy cow, fat, milk yield, transition period

\section{INTRODUCTION}

Several studies have been conducted on the effects of dietary fat supplementation on performance, DMI, and milk yield of dairy cows (Onetti et al., 2001; Juchem et al., 2008; Duske et al., 2009) but only a few studies have been undertaken to examine the effects of fat supplementation in transition dairy cows (Grum et al., 1996; Douglas et al., 2004). The transition period begins 3 wk before calving and lasts until 3 wk after calving (Bell et al., 1995) and is associated with an increased risk of metabolic- and production-related diseases (Friggens et al., 2004). This period is marked by a decrease in DMI (Grummer, 1995) and negative energy balance (Rabelo et al., 2003) due to the increasing demand of nutrients for milk production (Bell et al., 1995). As a result, body reserves are mobilized in an attempt to overcome the energy deficit as indicated by increased blood NEFA concentrations (Douglas et al., 2004), which, in turn, may reduce milk yield potential and persistency (Rabelo et al., 2003). According to the NRC (2001), maximizing energy intake during the close-up or prefresh period may rectify this situation in the postpartal period. Fat supplementation during the transition period is one strategy to enhance energy consumption, which then may assist in managing extensive physiological changes in dairy cows.

One theoretical basis for feeding fat to cows prepartum is to prime the cow to adapt to body fat in 
the following early lactation (Andersen et al., 2008), which may increase the $\beta$-oxidation capacity of longchain FA in the liver and decrease liver triacylglycerol concentration in the following early lactation (Grum et al., 1996). Because major changes occur before calving in the transition period, implementation of nutritional strategies at this time may have beneficial effects on performance. For example, supplementing dry cows with a saturated source of FA in a feed-restricted diet has been shown to be a positive strategy for priming dairy cows to mobilize body fat in the following early lactation. Moreover, dry cows fed for ad libitum intake a diet with $3.3 \%$ flaxseed had higher concentrations of glycogen and lower concentrations of triglyceride (TG) in the liver after calving, which may prevent the development of fatty liver (Petit et al., 2007). Therefore, the main objective of the current study was to determine the effects of fat supplementation during the prepartal and postpartal periods and their interactions on feed intake, animal performance, and milk production of dairy cows. Two levels of fat were offered for $21 \mathrm{~d}$ of the dry period in an attempt to quantify the effects of dietary fat level on the subsequent lactation performance. The hypothesis was that different fat levels fed during the prepartal and postpartal periods have a differential influence on the productivity of dairy cows.

\section{MATERIALS AND METHODS}

\section{Cows, Experimental Design, and Treatments}

The experiment was conducted at the Dairy Research Facilities of the Lavark Research Station of Isfahan University of Technology (Isfahan, Iran) using a total of 24 cows. Guidelines for the care and use of animals were approved by the Animal Care Committee of the university. The experiment was carried out from $21 \mathrm{~d}$ relative to parturition up to d 56 of lactation. Cows were blocked for similar expected calving dates. All cows in the study calved within 1 wk. Cows within groups were assigned randomly to 1 of 4 treatments (Table 1) in a $2 \times 2$ factorial arrangement of 2 levels of fat fed during the prepartal period and 2 levels of fat fed during the postpartal period: prepartal low fat and postpartal low fat (LF-LF), prepartal low fat and postpartal high fat (LF-HF), prepartal high fat and postpartal low fat (HF-LF), and prepartal high fat and postpartal high fat (HF-HF). At the beginning of the experiment, cows had similar parity (parity 4) and they averaged (mean $\pm \mathrm{SD}) 743 \pm 65 \mathrm{~kg}$ of $\mathrm{BW}$ and $3.5 \pm 0.05$ of BCS on a scale of 1 to 5 (3.45 for cows fed LF and 3.50 for cows fed HF; Edmonson et al., 1989). Prepartal and postpartal LF diets contained no fat supplement. The prepartal HF diet contained $1.60 \%$ calcium salts of soybean oil (CaSO). The proportion of CaSO was increased to $1.70 \%$ of DM for the first 21 d of lactation and to $2.27 \%$ of DM from d 21 to 56 of lactation in diet $\mathrm{HF}$.

Cows were housed in tie-stalls and allowed to exercise for $1 \mathrm{~h}$ every afternoon. They were milked 3 times per day at 0600,1400 , and $2200 \mathrm{~h}$ and milk production was recorded at each milking. Cows were fed individually at 0800 and $1600 \mathrm{~h}$ for 5 to $10 \%$ refusals and daily DMI was recorded. Body weight was recorded weekly. The FA profile of CaSO (Megalac; Behparvaran Co., Esfahan, Iran), expressed as a percentage of total FA, included $0.1 \% 12: 0,0.1 \%$ 14:0, $10.7 \%$ 16:0, $0.3 \% 16: 1$, $4.6 \% 18 \cdot 0,29.2 \%$ cis-9 18:1, $49.6 \%$ cis- $618: 2,5.3 \%$ cis3 18:3, and 0.1\% 20:0.

\section{Sampling}

Samples of the total mixed diets were taken weekly, frozen, and pooled on a 4 -wk basis. Composited samples were mixed thoroughly and subsampled for chemical analyses. Milk samples were obtained from each cow once per week from the 3 consecutive milkings. Milk samples were pooled to the corresponding milk yield and kept at room temperature (i.e., $23^{\circ} \mathrm{C}$ ) with the preservative potassium dichromate. Fat-corrected milk yield was calculated as $(0.4 \times \mathrm{kg}$ of milk $)+15(\mathrm{~kg}$ of milk $\times$ milk fat/100). Energy-corrected milk yield was calculated as $(0.327 \times \mathrm{kg}$ of milk $)+(12.95 \times \mathrm{kg}$ of fat $)+(7.2 \times \mathrm{kg}$ of protein $)$. Estimated energy balance (EB) was calculated postpartum for each cow using the following equations from NRC (2001): postpartum $\mathrm{EB}=$ net energy of intake $-\left(\mathrm{NE}_{\mathrm{M}}+\mathrm{NE}_{\mathrm{L}}\right)$. Net energy of intake $\left(\mathrm{NE}_{\mathrm{I}}\right)$ was calculated by multiplying DMI by the calculated net energy value of the diet; $\mathrm{NE}_{\mathrm{M}}=0.08$ $\times \mathrm{BW}^{0.75} ; \mathrm{NE}_{\mathrm{L}}=[(0.0929 \times \%$ fat $)+(0.0547 \times \%$ protein $)+(0.0395 \times \%$ lactose $)] \times$ milk production.

Blood was collected from all cows once per wk $3 \mathrm{~h}$ after the morning meal from $21 \mathrm{~d}$ before the expected calving day until $56 \mathrm{~d}$ postpartum. Blood was withdrawn from the jugular vein into Vacutainer tubes (Becton, Dickinson and Co., Franklin Lakes, NJ) containing lithium heparin and immediately put on ice. Tubes were centrifuged at $3,000 \times g$ for $20 \mathrm{~min}$ at $0^{\circ} \mathrm{C}$ within $2 \mathrm{~h}$ of sampling. The plasma were separated and frozen at $-20^{\circ} \mathrm{C}$ for subsequent analysis.

\section{Chemical Analyses}

The DM content of diets was determined by drying at $55^{\circ} \mathrm{C}$ for $48 \mathrm{~h}$ (Sadri et al., 2009). Total mixed dried diets were ground to pass a 1-mm screen in a Wiley mill (Ogawa Seiki Co. Ltd., Tokyo, Japan) before chemical analyses. Samples were stored at $-20^{\circ} \mathrm{C}$ for 
Table 1. Ingredient composition and chemical composition of the diet offered prepartum and postpartum ${ }^{1}$

\begin{tabular}{|c|c|c|c|c|c|c|}
\hline \multirow[b]{3}{*}{ Item } & \multirow{2}{*}{\multicolumn{2}{|c|}{$\frac{\text { Prepartum }}{-21 \text { to } 0 \text { DIM }}$}} & \multicolumn{4}{|c|}{ Postpartum } \\
\hline & & & \multicolumn{2}{|c|}{1 to $21 \mathrm{DIM}$} & \multicolumn{2}{|c|}{22 to 56 DIM } \\
\hline & $\mathrm{LF}$ & $\mathrm{HF}$ & $\mathrm{LF}$ & $\mathrm{HF}$ & $\mathrm{LF}$ & $\mathrm{HF}$ \\
\hline \multicolumn{7}{|l|}{ Ingredient, $\%$ of $\mathrm{DM}$} \\
\hline Corn silage & 32.1 & 21.0 & 28.9 & 29.1 & 32.1 & 31.8 \\
\hline Alfalfa hay & 12.2 & 12.2 & 9.68 & 1.10 & 7.93 & 7.86 \\
\hline Barley & 9.76 & 9.13 & 3.70 & 9.88 & 3.90 & 12.7 \\
\hline Corn & 6.90 & 6.50 & 28.1 & 28.1 & 25.8 & 6.27 \\
\hline Beet pulp & - & - & - & - & - & 5.35 \\
\hline Soybean meal ( $45 \% \mathrm{CP})$ & 23.6 & 23.0 & 17.9 & 18.4 & 14.5 & 4.21 \\
\hline Canola meal & 1.29 & 4.76 & - & - & - & - \\
\hline Wheat straw & 3.37 & 4.60 & - & - & - & - \\
\hline Wheat bran & 3.37 & 9.80 & - & - & - & - \\
\hline Cotton seed & - & - & 2.50 & 2.50 & 6.40 & 6.40 \\
\hline Cotton seed meal & - & - & 7.50 & 7.50 & 6.80 & 20.9 \\
\hline Vitamin and mineral mix $1^{2}$ & 3.60 & 3.50 & - & - & - & - \\
\hline Vitamin and mineral mix $2^{3}$ & - & - & 0.56 & 0.56 & 0.59 & 0.59 \\
\hline Calcium salts of soybean oil ${ }^{4}$ & - & 1.60 & - & 1.70 & - & 2.27 \\
\hline Anionic salt premix ${ }^{5}$ & 0.35 & 0.35 & - & - & - & - \\
\hline Sodium bicarbonate & - & - & 0.7 & 0.7 & 1.0 & 1.0 \\
\hline Dicalcium phosphate & - & - & 0.31 & 0.31 & - & - \\
\hline Ammonium chloride & 3.46 & 3.46 & - & - & - & - \\
\hline Vitamin $\mathrm{E}+\mathrm{Se}^{6}$ & - & - & 0.05 & 0.05 & 0.20 & 0.20 \\
\hline Salt & - & - & 0.10 & 0.10 & 0.20 & 0.20 \\
\hline Calcium carbonate & - & - & - & - & 0.50 & 0.17 \\
\hline Iron sulfate & - & - & - & - & 0.08 & 0.08 \\
\hline \multicolumn{7}{|l|}{ Chemical composition, \% of DM } \\
\hline $\mathrm{NE}_{\mathrm{L}}{ }^{7} \mathrm{Mcal} / \mathrm{kg}$ & 1.55 & 1.55 & 1.65 & 1.65 & 1.60 & 1.61 \\
\hline $\mathrm{CP}$ & 14.60 & 14.6 & 17.0 & 17.0 & 17.0 & 17.0 \\
\hline Lipid & 2.5 & 3.8 & 3.2 & 4.2 & 3.9 & 5.6 \\
\hline NDF & 34.0 & 36.0 & 41.00 & 37.0 & 37.0 & 30.0 \\
\hline $\mathrm{NFC}^{8}$ & 35.0 & 32.4 & 25.00 & 26.0 & 27.0 & 28.0 \\
\hline $\mathrm{Ca}^{7}$ & 1.20 & 1.40 & 1.00 & 1.10 & 0.57 & 0.64 \\
\hline $\mathrm{P}^{7}$ & 0.34 & 0.33 & 0.40 & 0.50 & 0.40 & 0.47 \\
\hline \multicolumn{7}{|l|}{${ }^{1} \mathrm{LF}=$ low fat; $\mathrm{HF}=$ high fat. } \\
\hline \multicolumn{7}{|c|}{$\begin{array}{l}{ }^{2} \text { Contained (DM basis) } 15.2 \% \mathrm{Ca}, 2.44 \% \mathrm{Mg}, 10.46 \% \mathrm{Cl}, 0.04 \% \mathrm{~K}, 0.82 \% \mathrm{Na}, 3.5 \% \mathrm{~S}, 1,400 \mathrm{mg} \text { of Fe } / \mathrm{kg} \text {, } \\
288.2 \mathrm{mg} \text { of } \mathrm{Mn} / \mathrm{kg}, 302.5 \mathrm{mg} \text { of Cu/kg, } 12.7 \mathrm{mg} \text { of I/kg, } 504 \mathrm{mg} \text { of } \mathrm{Zn} / \mathrm{kg}, 150 \mathrm{kIU} \text { of vitamin A/kg, } 50 \mathrm{kIU} \\
\text { of vitamin } \mathrm{D}_{3} / \mathrm{kg} \text {, and } 2,000 \mathrm{IU} \text { of vitamin E } / \mathrm{kg} \text {. } \\
{ }^{3} \mathrm{Contained} 12 \% \mathrm{Ca}, 2 \% \mathrm{P}, 2.05 \% \mathrm{Mg}, 18.6 \% \mathrm{Na}, 0.3 \% \mathrm{~S}, 1,250 \mathrm{mg} \text { of Fe } / \mathrm{kg}, 2,250 \mathrm{mg} \text { of Mn } / \mathrm{kg}, 7,700 \mathrm{mg} \text { of } \\
\mathrm{Zn} / \mathrm{kg}, 14 \mathrm{mg} \text { of Co } / \mathrm{kg}, 1,250 \mathrm{mg} \text { of Cu} / \mathrm{kg}, 56 \mathrm{mg} \text { of I } / \mathrm{kg}, 10 \mathrm{mg} \text { of Se } / \mathrm{kg}, 250 \mathrm{kIU} \text { of vitamin A } / \mathrm{kg}, 50 \mathrm{kIU} \\
\text { of vitamin } \mathrm{D}_{3} / \mathrm{kg}, 1.5 \mathrm{kIU} \text { of vitamin } \mathrm{E} / \mathrm{kg} \text {. }\end{array}$} \\
\hline
\end{tabular}

further analysis. Fat, protein, lactose, and SNF concentrations in milk samples were analyzed by infrared spectrophotometry (MilkoScan, 134 BN; Foss Electric A/S, Hillerød, Denmark) according to methods of AOAC International (2007). Monthly composite TMR samples were analyzed for CP (AOAC, 1990; method 988.05), NDF without the use of sodium sulfite and with the inclusion of $\alpha$-amylase (Van Soest et al. 1991), ADF (AOAC, 1990; method 973.18), lipids (AOAC, 1990; method 920.39), and ash (AOAC, 1990; method 942.05). Plasma concentrations of cholesterol, TG, very low density lipoprotein (VLDL), low-density lipopro- tein (LDL), and high-density lipoprotein (HDL) were determined by an automated biochemical analyzer (Technicon RA 1000; Bayer, NY) using commercial kits (Pars Azmoon Co., Tehran, Iran) according to the manufacturer's instructions.

\section{Statistical Analyses}

Measurements of DMI and milk yield were reduced to weekly means before statistical analysis. Data were analyzed as repeated measures using PROC MIXED of SAS (SAS Institute, 2002) and they were analyzed 
Table 2. Effect of prepartum diet on mean DMI, BW, and blood metabolite concentrations during the prepartum period (from $\mathrm{d}-21$ to 0 relative to calving)

\begin{tabular}{|c|c|c|c|c|c|}
\hline \multirow[b]{2}{*}{ Item } & \multicolumn{2}{|c|}{ Prepartum dietary regimen } & \multirow[b]{2}{*}{ SEM } & \multicolumn{2}{|c|}{$P$-value } \\
\hline & $\mathrm{LF}$ & $\mathrm{HF}$ & & Diet & Week \\
\hline DMI, kg/d & 16.2 & 12.6 & 0.15 & $<0.001$ & $<0.001$ \\
\hline DMI, $\%$ of BW & 2.14 & 1.75 & 0.02 & $<0.001$ & $<0.001$ \\
\hline Mean BW, kg & 762 & 725 & 11.3 & 0.26 & $<0.001$ \\
\hline \multicolumn{6}{|l|}{ Plasma metabolite $^{1}$} \\
\hline $\mathrm{TG}, \mathrm{mmol} / \mathrm{L}$ & 0.37 & 0.40 & 0.02 & 0.43 & $<0.001$ \\
\hline Cholesterol, mmol/L & 2.37 & 2.35 & 0.13 & 0.95 & 0.001 \\
\hline $\mathrm{HDL}, \mathrm{mmol} / \mathrm{L}$ & 1.73 & 1.80 & 0.09 & 0.84 & $<0.001$ \\
\hline $\mathrm{LDL}, \mathrm{mmol} / \mathrm{L}$ & 0.68 & 0.75 & 0.06 & 0.63 & 0.17 \\
\hline VLDL, $\mathrm{mmol} / \mathrm{L}$ & 0.08 & 0.17 & 0.02 & 0.17 & $<0.001$ \\
\hline LDL/HDL & 0.36 & 0.39 & 0.03 & 0.78 & 0.15 \\
\hline
\end{tabular}

${ }^{1} \mathrm{TG}=$ triglyceride; $\mathrm{HDL}=$ high-density lipoprotein; $\mathrm{LDL}=$ low-density lipoprotein; VLDL = very low density lipoprotein.

separately for the prepartal and postpartal periods. For prepartal data, the model included the fixed effects of treatment and week. For postpartal data, the model included the fixed effects of prepartal fat level, postpartal fat level, and week. The models included all 2 -way and 3-way interactions. Initial BW of cows was used as covariate for the analysis of BW. The firstorder autoregressive $[\mathrm{AR}(1)]$ was used as the covariance structure and cow within treatment was set as a random effect. When differences $(P<0.05)$ due to interactions or dietary treatments were detected, means separation was conducted using a Tukey adjustment for the probability. Significance was declared at $P \leq 0.05$ and trends were considered at $0.05<P<0.10$.

\section{RESULTS AND DISCUSSION}

\section{Prepartal Performance and Plasma Concentration of Metabolites}

Cows showed no health problems before calving. As no interactions existed between diet and week for any prepartal measurements, only the mean values were presented (Table 2). Fat supplementation prepartum significantly affected prepartal DMI, expressed in kilograms per day and as a percentage of BW, with lower intake $(P<0.01)$ for cows fed the HF diet compared with those fed the LF diet (Table 2). Several studies have found that decreased intake resulted from abomasal infusion of unsaturated FA (Drackley et al., 1992; Bremmer et al., 1998) or from feeding cows increasing amounts of unsaturated FA at the expense of SFA (Harvatine and Allen, 2006). In addition, feeding transition cows with the calcium salts of long-chain FA rich in PUFA decreased DMI prepartum compared with prilled fat rich in SFA (Moallem et al., 2007). Effects of prepartal fat supplementation have been inconsistent, with fat supplementation reported to decrease (Grum et al., 1996; Duske et al. 2009; Moallem et al. 2007) or not affect (Afzalzadeh et al., 2010) DMI of dairy cows. Discrepancies between studies could be attributed to differences between amounts and forms of fat supplements and palatability of fat sources (Zachut et al., 2010). According to Relling et al. (2010), the negative effects of a high-fat diet on DMI can result partly because of inhibition of fiber digestion by unsaturated fat sources, lower palatability of the diet, and metabolic regulation of intake by cholecystokinin on brain satiety centers (Reidelberger, 1994). Prepartal fat level had no effect on BW (Table 2).

Mean plasma concentrations of TG, cholesterol, HDL, LDL, and VLDL and the LDL-to-HDL ratio were not significantly affected $(P>0.05)$ by prepartal fat level during the last $3 \mathrm{wk}$ of gestation (Table 2). This agrees with the results of Mendoza et al. (2008), who reported similar plasma cholesterol concentrations in grazing cows fed up to $1.4 \mathrm{~kg}$ of whole sunflower seed daily during the prepartal and postpartal periods. A significant time effect was detected for plasma concentrations of TG, cholesterol, HDL, and VLDL as a result of increased concentrations from d 21 prepartum up to calving (data not shown).

\section{Postpartal Performance and Production}

No significant 3-way interactions (week of lactation $\times$ prepartal treatment $\times$ postpartal treatment) were detected in the present experiment. However, all parameters were affected by week of lactation (data not shown). Postpartal performance and production were affected similarly from d 1 to 56 of lactation among treatments, as indicated by the lack of significant interactions between treatment and week of lactation. Therefore, only the mean values for the 56-d period of lactation are presented (Table 3). After calving, a significant interaction existed between prepartal and 
Table 3. Effect of pre- and postpartal fat levels on intake and production parameters of dairy cows from d 1 to 56 of lactation

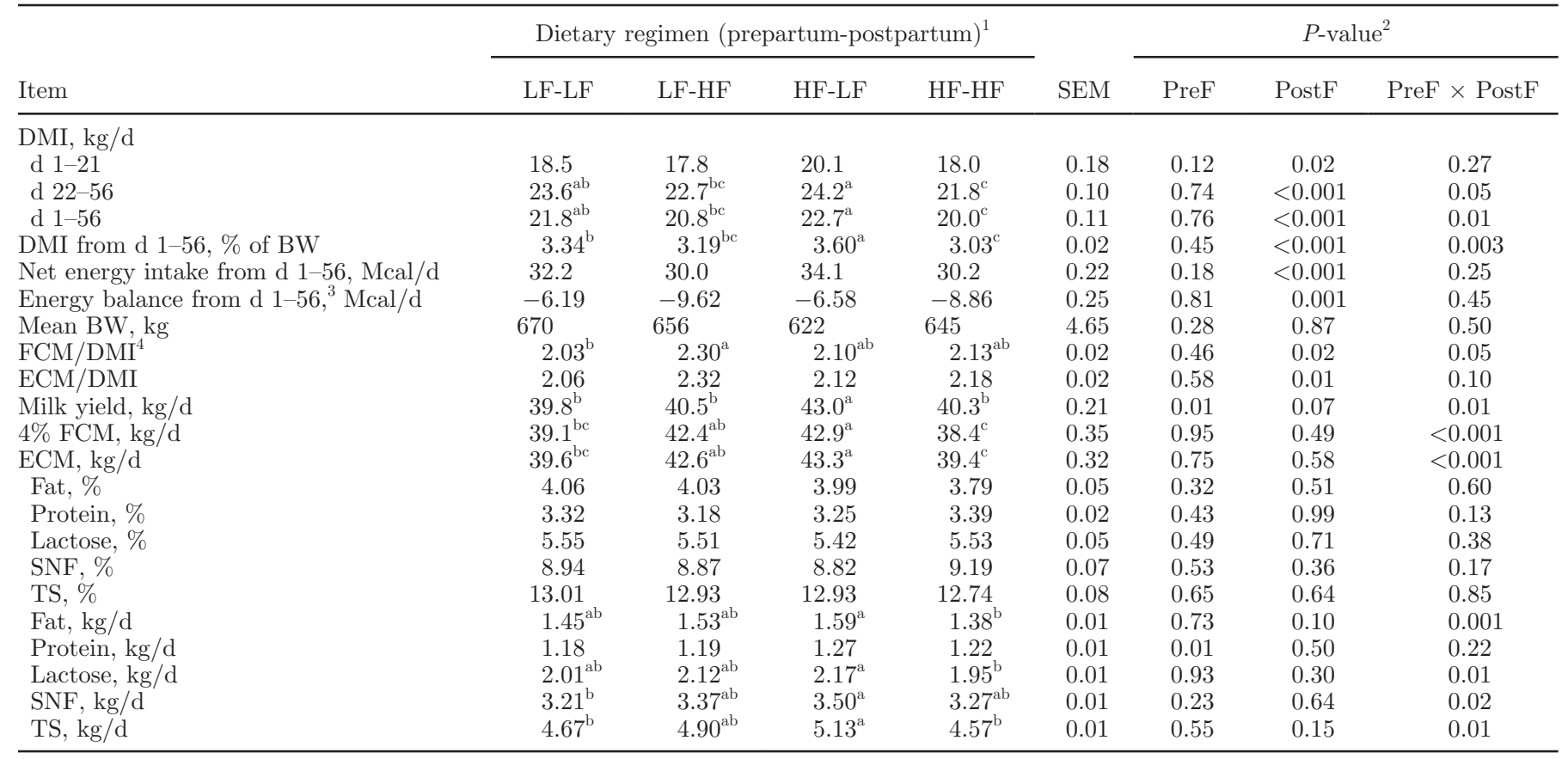

${ }^{\mathrm{a}-\mathrm{c}}$ Means with different superscript letters within a row are different $(P \leq 0.05)$.

${ }^{1} \mathrm{LF}-\mathrm{LF}=$ low fat prepartum and low fat postpartum; LF-HF = low fat prepartum and high fat postpartum; HF-LF = high fat prepartum and low fat postpartum; HF-HF = high fat prepartum and high fat postpartum.

${ }^{2}$ PreF $=$ prepartum fat level; PostF $=$ postpartum fat level.

${ }^{3}$ Negative energy balance $(\mathrm{NEB})$ calculated based on NRC $(2001)$. Postpartum NEB $=($ DMI $\times$ NEL diet $)-\left[\left(0.08 \times \mathrm{BW}^{0.75}\right)+(0.0929 \times\right.$ fat $+0.0563 \times$ protein $+0.0395 \times$ lactose $) \times$ milk yield $)]$.

${ }^{4} \mathrm{FCM} / \mathrm{DMI}=$ efficiency of milk production.

postpartal diets for DMI, expressed in kilograms per day and as a percentage of BW (Table 3). Cows fed the HF-HF diet had the lowest DMI and those fed the HF-LF diet had the highest DMI and no significant differences existed between HF-LF and LF-LF. Lower prepartal DMI of cows fed the HF diet compared with those fed the LF diet did not lower postpartal DMI of cows fed the postpartal LF diet, which may indicate that the decrease in postpartal DMI was not attributable solely to lower DMI prepartum as previously reported by others (Butler et al., 2002; McNamara et al., 2003). The proportion of unsaturated FA of the CaSO was high, which may have contributed to decrease DMI of cows fed the postpartal HF diet compared with those fed the postpartal LF diet. This agrees with the results of Moallem et al. (2007), who found lower DMI when transition cows were supplemented with unsaturated compared with SFA. Similar decreases in DMI with increased content of unsaturated FA in the fat supplement have been reported by others (Drackley et al., 1992; Chilliard et al., 2009). This is corroborated by the lack of effects of prepartal rumen-inert hydrogenated FA supplementation on DMI of dairy cows during the first $21 \mathrm{~d}$ postpartum (Afzalzadeh et al., 2010).
Prepartal treatment had no effect on BW of cows after calving, which agrees with the results of Grummer et al. (1995), who reported no effect of prepartal tallow supplementation $(2.8 \%$ of DM) on BW of dairy cows during the first $150 \mathrm{~d}$ of lactation. Differences in net energy intake and cumulative EB between the postpartal treatments were greater in cows fed the postpartal LF diet compared with those fed the postpartal HF diet. No interaction was detected between pre- and postpartal fat level for net energy intake and cumulative EB (Table 3).

Cows offered the prepartal HF diet had higher milk yield when offered the postpartal LF diet compared with those offered the postpartal HF diet and no effect of the postpartal fat level was detected when cows were fed the prepartal LF diet, as a result of a significant interaction between fat level fed during the prepartal and postpartal periods (Table 3). According to Afzalzadeh et al. (2010), increased milk yield in early lactation associated with fat supplementation is largely attributed to an enhanced EB, thus ensuring that other sources of energy such as amino acids (i.e., glucogenic precursors) are used for milk production. An interaction existed between prepartal and postpartal fat levels for efficiency 
of milk production (Table 3), as indicated by better efficiency for cows fed the LF-HF diet due to lower DMI. The lowest yields of $4 \% \mathrm{FCM}$ and ECM were obtained for cows fed the HF-HF diet and no difference existed between cows fed the HF-HF and LF-LF diets.

The proportion of milk fat was similar among diets, but the yield of milk fat was higher for cows fed the HF-LF diet compared with those fed the HF-HF diet and those fed the LF-LF and LF-HF diet had intermediate values. Conflicting results have been reported regarding the effects of fat supplementation on milk fat proportion in dairy cows. Studies reported decreases (Grummer and Carroll, 1991; Palmquist, 1994), no effect (Mandebvu et al., 2003; Reis et al., 2012), or increases (Selberg et al., 2004; Relling and Reynolds, 2007) in milk fat proportion with dietary fat supplementation. Discrepancies between studies may result of differences in the amounts and forms of supplemental fat or to interactions with other diet components, as suggested by Chilliard et al. (2009). Differences in milk fat yield among treatments mainly reflected those observed for milk yield.

Proportions of milk protein and lactose were similar among diets, which agree with the findings of Afzalzadeh et al. (2010), who supplemented the diet of dry cows with $3.3,5.0$, or $6.5 \%$ fat in the DM during the last $21 \mathrm{~d}$ of gestation. Cows fed the HF-HF and the HF-LF diet had the lowest and highest milk yield of lactose, respectively, and those fed the other diets had intermediate values, as shown by the interaction between prepartal and postpartal fat levels. Proportions of SNF and TS in milk were similar among diets, but the highest yield of TS was obtained for cows fed the HF-LF diet and the lowest for cows fed the HF-HF diet.

\section{Postpartal Plasma Concentration of Metabolites}

No interactions were detected between prepartal and postpartal fat levels for concentrations of cholesterol,
TG, HDL, LDL, and VLDL and the LDL-to-HDL ratio in plasma of postpartal cows. Prepartal diet had no significant effect on postpartal plasma TG concentration (Table 4), which agrees with the findings of Nagao et al. (2005), who reported that prepartal supplementation with SFA had no effect on plasma TG accumulation after parturition. The postpartal HF diet increased TG and LDL concentrations compared with the postpartal LF diet, which was likely a result of a higher rate of TG production in the liver of cows fed the former diet, as previously reported for cows around calving (Grum et al., 1996; Litherland et al., 2011). According to Lough et al. (1988), higher plasma TG concentration is consistent with increased absorption of long-chain FA in the small intestine. Similarly, Duske at al. (2009) reported that cows fed a source of rumen-protected fat in the diet had higher plasma TG concentration than those fed a control diet without supplemental fat during the first $21 \mathrm{~d}$ after calving.

Prepartal fat level had no significant effect on plasma concentrations of TG, HDL, LDL, and the LDL-to-HDL ratio, and postpartal fat level had no effect on plasma concentrations of cholesterol, HDL, VLDL, and the LDL-to-HDL ratio (Table 4). However, prepartal diet had a significant effect on plasma VLDL concentrations during the postpartal period (Table 4). After calving, cows offered the prepartal HF diet had higher plasma VLDL concentrations than those offered the prepartal LF diet, which could result from the lower DMI observed during the prepartal period. Indeed, Duske et al. (2009) reported that prepartal fat supplementation lowers DMI prepartum and increases plasma concentration of triacylglycerol postpartum. Plasma lipoproteins carrying large amounts of triacylglycerol are chylomicrons and VLDL secreted by the liver, which can elevate transportation of accumulated TG from the liver to peripheral tissue and decrease hepatic lipidosis (Oikawa et al. 2010). Stimulation of hepatic VLDL formation and export might lead to a reduction in liver TG ac-

Table 4. Effect of pre- and postpartum diets on blood metabolite concentrations of dairy cows from d 1 to 56 of lactation

\begin{tabular}{|c|c|c|c|c|c|c|c|c|}
\hline Item $^{1}$ & \multicolumn{4}{|c|}{ Dietary regimen (prepartum-postpartum) ${ }^{2}$} & SEM & \multicolumn{3}{|c|}{$P$-value ${ }^{3}$} \\
\hline $\mathrm{TG}, \mathrm{mmol} / \mathrm{L}$ & 0.22 & 0.27 & 0.24 & 0.25 & 0.006 & 0.65 & 0.02 & 0.11 \\
\hline $\mathrm{HDL}, \mathrm{mmol} / \mathrm{L}$ & 3.25 & 2.77 & 2.32 & 3.56 & 0.26 & 0.91 & 0.58 & 0.22 \\
\hline LDL, mmol/L & 1.40 & 2.07 & 0.99 & 1.68 & 0.10 & 0.20 & 0.04 & 0.98 \\
\hline VLDL, $\mathrm{mmol} / \mathrm{L}$ & 0.05 & 0.05 & 0.16 & 0.14 & 0.001 & 0.02 & 0.94 & 0.84 \\
\hline
\end{tabular}

${ }_{\mathrm{a}, \mathrm{b}}$ Means with different superscript letters within a row are different $(P \leq 0.05)$.

${ }^{1} \mathrm{TG}=$ triglyceride; HDL = high-density lipoprotein; LDL = low-density lipoprotein; VLDL = very low density lipoprotein.

${ }^{2} \mathrm{LF}-\mathrm{LF}=$ low fat prepartum and low fat postpartum; LF-HF = low fat prepartum and high fat postpartum; HF-LF $=$ high fat prepartum and low fat postpartum; HF-HF = high fat prepartum and high fat postpartum.

${ }^{3} \mathrm{PreF}=$ prepartum fat level; PostF $=$ postpartum fat level. 
cumulation and of ketone body production (Bauchart et al., 1998), which could contribute to minimize the risk of ketosis and fatty liver (Kronfeld, 1982).

Plasma cholesterol concentration postpartum was higher $(P=0.02)$ for cows fed the prepartal LF diet than for those fed the prepartal HF diet and postpartal fat level had no effect. Although the prepartal LF diet had a lower ether extract percentage than the prepartal HF diet, prepartal intake of ether extract was higher for cows fed the former (478 vs. $405 \mathrm{~g} / \mathrm{d}$ ) a result of higher DMI. Higher plasma cholesterol concentrations have been reported in dairy cows fed supplemental fat (Andersen et al., 2008), which was likely a result of increased intestinal and hepatic cholesterol synthesis (Grummer and Carroll, 1988).

All treatments significantly increased cholesterol concentrations in plasma after parturition and the response to treatment was similar among diets, as indicated by the lack of interaction between diet and week of lactation (data not shown). Similarly, increased plasma cholesterol concentrations in cows fed Ca salts of FA during the first $21 \mathrm{~d}$ postpartum have been reported by Duske et al. (2009). Moreover, other studies have shown increased concentration of plasma cholesterol when feeding supplemental fat, such as saturated fat or linseed, to lactating dairy cows, which likely resulted from a greater demand for cholesterol to digest, absorb, and transport the increased amounts of long-chain FA reaching the small intestine (Drackley et al., 1992; Andersen et al., 2008). Moreover, Douglas et al. (2004) indicated that supplemental liquid fat fed at $3.64 \%$ of DM during the prepartal period increased plasma concentration of cholesterol during the prepartal period and after parturition.

Plasma concentrations of cholesterol, TG, HDL, LDL, and VLDL increased significantly from calving up to d 56 of lactation (data not shown). This agrees with the results of Nagao et al. (2005), who noted that plasma HDL-cholesterol concentration gradually increased during the postpartal period and reached a plateau after 5 to 6 wk of lactation.

\section{CONCLUSIONS}

No benefit was detected from feeding a high fat level in the diet during the prepartal period, as it reduced DMI compared with a low fat level.

\section{ACKNOWLEDGMENTS}

This study was financed by Isfahan University of Technology (Isfahan, Iran). The authors appreciate the employees of the Lavark Research Station (Isfahan University of Technology) for animal care.

\section{REFERENCES}

Afzalzadeh, A., M. H. Palizdar, H. Mahmoudzadeh, and A. NiasariNaslaji. 2010. Effect of fat supplementation during transition period on plasma leptin and non-esterified fatty acid concentrations in Holstein cows. Anim. Sci. J. 81:309-315.

Andersen, J. B., C. Ridder, and T. Larsen. 2008. Priming the cow for mobilization in the periparturient period: Effects of supplementing the dry cow with saturated fat or linseed. J. Dairy Sci. 91:1029-1043.

AOAC. 1990. Official Methods of Analysis. 14th ed. Association of Official Analytical Chemists, Arlington, VA.

AOAC International. 2007. Official Methods of Analysis. 19th ed. AOAC International, Washington, DC.

Bauchart, D., D. Durand, D. Gruffat, and Y. Chilliard. 1998. Mechanism of liver steatosis in early lactation cows: Effects of hepatoprotector agents. Pages 27-37 in Proc. Cornell Nutr. Conf. Feed Manuf. Cornell University, Ithaca, NY.

Bell, A. W., R. Slepetis, and R. A. Ehrhardt. 1995. Growth and accretion of energy and protein in the gravid uterus during late pregnancy in Holstein cows. J. Dairy Sci. 78:1954-1961.

Bremmer, D. R., L. D. Ruppert, J. H. Clark, and J. K. Drackley. 1998. Effects of chain length and unsaturation of fatty acid mixtures infused into the abomasum of lactating dairy cows. J. Dairy Sci. 81:176-188.

Butler, S. T., J. J. Murphy, G. K. Stakelum, F. P. O'Mara, and M. Rath. 2002. Influence of transition diets on the performance and metabolic profile of dairy cows both pre- and postpartum. Ir. J. Agric. Food Res. 41:71-85.

Chilliard, Y., C. Martin, J. Rouel, and M. Doreau. 2009. Milk fatty acids in dairy cows fed whole crude linseed, extruded linseed, or linseed oil, and their relationship with methane output. J. Dairy Sci. 92:5199-5211.

Douglas, G. N., T. R. Overton, H. G. Bateman, and J. K. Drackley. 2004. Peripartal metabolism and production of Holstein cows fed diets supplemented with fat during the dry period. J. Dairy Sci. $87: 4210-4220$.

Drackley, J. K., T. H. Klusmeyer, A. M. Trusk, and J. H. Clark. 1992. Infusion of long-chain fatty acids varying in saturation and chain length into the abomasum of lactating dairy cows. J. Dairy Sci. $75: 1517-1526$.

Duske, K., H. M. Hammon, A.-K. Langhof, O. Bellmann, B. Losand, K. Nürnberg, G. Nürnberg, H. Sauerwein, H. M. Seyfert, and C. C. Metges. 2009. Metabolism and lactation performance in dairy cows fed a diet containing rumen-protected fat during the last twelve weeks of gestation. J. Dairy Sci. 92:1670-1684.

Edmonson, A. J., I. J. Lean, L. D. Weaver, T. Farver, and G. Webster 1989. A body condition scoring chart for Holstein dairy cows. J. Dairy Sci. $72: 68-78$.

Friggens, N. C., J. B. Andersena, T. Larsena, O. Aaesb, and R. J. Dewhurst. 2004. Priming the dairy cow for lactation: a review of dry cow feeding strategies. Anim. Res. 53:453-473.

Grum, D. E., J. K. Drackley, R. S. Younker, D. W. LaCount, and J. J. Veenhuizen. 1996. Nutrition during the dry period and hepatic lipid metabolism of periparturient dairy cows. J. Dairy Sci. 79:1850-1864.

Grummer, R. R. 1995. Impact of changes in organic nutrient metabolism on feeding the transition dairy cow. J. Anim. Sci. 73:28202833

Grummer, R. R., and D. J. Carroll. 1988. A review of lipoprotein cholesterol metabolism: Importance to ovarian function. J. Anim. Sci. $66: 3160-3173$.

Grummer, R. R., and D. J. Carroll. 1991. Effects of dietary fat on metabolic disorders and reproductive performance of dairy cattle. J. Anim. Sci. 69:3838-3852.

Grummer, R. R., P. C. Hoffman, M. L. Luck, and S. J. Bertics. 1995. Effect of prepartum and postpartum dietary energy on growth and lactation of primiparous cows. J. Dairy Sci. 78:172-180.

Harvatine, K. J., and M. S. Allen. 2006. Effects of fatty acid supplements on milk yield and energy balance of lactating dairy cows. J. Dairy Sci. 89:1081-1091. 
Juchem, S. O., J. E. P. Santos, R. L. A. Cerri, R. C. Chebel, K. N. Galvão, R. Bruno, E. J. DePeters, T. Scott, W. W. Thatcher, and D. Luchini. 2008. Effect of calcium salts of fish and palm oils on lactational performance of Holstein cows. Anim. Feed Sci. Technol. 140:18-38.

Kronfeld, D. S. 1982. Major metabolic determinants of milk volume, mammary efficiency, and spontaneous ketosis in dairy cows. J. Dairy Sci. 65:2204-2212.

Litherland, N. B., H. M. Dann, and J. K. Drackley. 2011. Prepartum nutrient intake alters palmitate metabolism by liver slices from peripartal dairy cows. J. Dairy Sci. 94:1928-1940.

Lough, D. S., L. D. Muller, R. S. Kensinger, T. F. Sweeney, and L. C. Griel Jr. 1988. Effect of added dietary fat and bovine somatotropin on the performance and metabolism of lactating dairy cows. J. Dairy Sci. 71:1161-1169.

Mandebvu, P., C. S. Ballard, C. J. Sniffen, M. P. Carter, H. M. Wolford, T. Sato, Y. Yabuuchi, E. Block, and D. L. Palmquist. 2003. Effect of feeding calcium salts of long-chain fatty acids, from palm fatty acid distillate or soybean oil, to high producing dairy cows on milk yield and composition, and on selected blood and reproductive parameters. Anim. Feed Sci. Technol. 108:25-41.

McNamara, S., T. Butler, D. P. Ryan, J. F. Mee, P. Dillon, F. P. O'Mara, S. T. Butler, D. Anglesey, M. Rath, and J. J. Murphy. 2003. Effect of offering rumen-protected fat supplements on fertility and performance in spring-calving Holstein-Friesian cows. Anim. Reprod. Sci. 79:45-56.

Mendoza, A., A. La Manna, D. Crespi, M. A. Crowe, and D. Cavestany. 2008. Whole sunflower seeds as a source of polyunsaturated fatty acids for grazing dairy cows: Effects on metabolic profiles and resumption of postpartum ovarian cyclicity. Livest. Sci. 119:183-193.

Moallem, U., M. Katz, A. Arieli, and H. Lehrer. 2007. Effects of peripartum propylene glycol or fats differing in fatty acid profiles on feed intake, production, and plasma metabolites in dairy cows. J. Dairy Sci. 90:3846-3856.

Nagao, K., Y. Takahara, H. Asai, N. Hayashi, T. Kitayama, Y. Yoshimura, H. Yokota, and K. Kita. 2005. Dietary fatty acid supplementation during transitional period increases milk production in dairy cows. Asian-australas. J. Anim. Sci. 18:1105-1109.

NRC. 2001. Nutrient Requirements of Dairy Cattle. 7th rev. ed. National Academic Press, Washington, DC.

Oikawa, S., Y. Mizunuma, Y. Iwasaki, and M. Tharwat. 2010. Changes of very low-density lipoprotein concentration in hepatic blood from cows with fasting-induced hepatic lipidosis. Can. J. Vet. Res. 74:317-320.
Onetti, S. G., R. D. Shaver, M. A. McGuire, and R. R. Grummer. 2001. Effect of type and level of dietary fat on rumen fermentation and performance of dairy cows fed corn silage-based diets. J. Dairy Sci. 84:2751-2759.

Palmquist, D. L. 1994. The role of dietary fats in efficiency of ruminants. J. Nutr. 124(Suppl.):1377S-1382S.

Petit, H. V., M. F. Palin, and L. Doepel. 2007. Hepatic lipid metabolism in transition dairy cows fed flaxseed. J. Dairy Sci. 90:47804792.

Rabelo, E., R. L. Rezende, S. J. Bertics, and R. R. Grummer. 2003. Effects of transition cow diets varying in dietary energy density on lactation performance and ruminal parameters of dairy cows. J. Dairy Sci. 86:916-925.

Reidelberger, R. D. 1994. Cholecystokinin and control of food intake. J. Nutr. 124:1327S-1333S.

Reis, M. M., R. F. Cooke, J. Ranches, and J. L. M. Vasconcelos. 2012. Effects of calcium salts of polyunsaturated fatty acids on productive and reproductive parameters of lactating Holstein cows. J. Dairy Sci. 95:7039-7050.

Relling, A. E., J. L. Pate, C. K. Reynolds, and S. C. Loerch. 2010. Effect of feed restriction and supplemental dietary fat on gut peptide and hypothalamic neuropeptide mRNA concentrations in growing wethers. J. Anim. Sci. 88:737-748.

Relling, A. E., and C. K. Reynolds. 2007. Feeding rumen-inert fats differing in their degree of saturation decreases intake and increases plasma concentrations of gut peptides in lactating dairy cows. J. Dairy Sci. 90:1506-1515.

Sadri, H., G. R. Ghorbani, H. R. Rahmani, A. H. Samie, M. Khorvash, and R. M. Bruckmaier. 2009. Chromium supplementation and substitution of barley grain with corn: Effects on performance and lactation in periparturient dairy cows. J. Dairy Sci. 92:5411-5418.

SAS Institute. 2002. SAS User's Guide: Statistics. Release 9.1. SAS Institute Inc., Cary, NC.

Selberg, K. T., A. C. Lowe, C. R. Staples, N. D. Luchini, and L. Badinga. 2004. Production and metabolic responses of periparturient Holstein cows to dietary conjugated linoleic acid and trans-octadecenoic acids. J. Dairy Sci. 87:158-168.

Van Soest, P. J., J. B. Robertson, and B. A. Lewis. 1991. Methods for dietary fiber, neutral detergent fiber, and nonstarch polysaccharides in relation to animal nutrition. J. Dairy Sci. 74:3583-3597.

Zachut, M., A. Arieli, H. Lehrer, L. Livshitz, S. Yakoby, and U. Moallem. 2010. Effects of increased supplementation of n-3 fatty acids to transition dairy cows on performance and fatty acid profile in plasma, adipose tissue, and milk fat. J. Dairy Sci. 93:5877-5889. 